\title{
Economic Sustainability of Vegetable Farming by Self-Help Group Members and Non Members: An Assertive Study in Himachal Pradesh
}

\author{
Surinder Singh ${ }^{1 *}$ and B.S. Hansra ${ }^{2}$ \\ ${ }^{1}$ School of Agriculture, Indira Gandhi National Open University, New Delhi, India \\ ${ }^{2}$ Amity International University, Noida, Uttar Pradesh, India \\ *Corresponding author: singhsurin@yahoo.com (ORCID ID: 0000-0002-7451-3437)
}

Received: $17-09-2021$

Revised: 24-11-2021

Accepted: 11-12-2021

\begin{abstract}
Vegetable cultivation have paved new path in economic development for farmers in Himachal Pradesh but information on future viability and sustainability is still lacking. This study was conducted in the state of Himachal Pradesh to find out economic sustainability index (ESI) for vegetable farms of SHG members vis-à-vis other farmers. The study revealed higher economic sustainability of vegetable farms belongs to SHG members in comparison to other farmers. Indicators of economic sustainability, viz. production efficiency, net profit and market accessibility were found to be significantly higher for SHG members than other farmers. Socioeconomic characteristics like education, land holding, vegetable production and extension contacts proved to have significant and positive effect on economic sustainability index. Although SHG approach found to improve economic sustainability in vegetable farming, very few vegetable farms found to be in highly sustainable category, So, there is untapped potential to cover more vegetable growing farmers under self-help groups to harness the benefits of group dynamics in strengthening vegetable production in the state.

\section{HIGHLIGHTS}

( Vegetable farms of SHG members are performing well in term of production efficiency, net profit, and market accessibility.

( Economic sustainability index was significantly higher for SHG member's vegetable farms than other farmers.

0 Farmers education status, operational land holding, vegetable production and extension contacts have significant and positive effect on economic sustainability index for vegetable farming.
\end{abstract}

Keywords: Economic sustainability, Vegetable farming, self-help groups, Himachal Pradesh

Practicing agriculture in hills is challenging and sturdy job. Mountain agriculture is more difficult due to some inherent constraints like small and marginal sloppy landholdings, lack of irrigation facilities, transportation and market access. Besides all constraints in practicing agriculture in mountainous regions, the importance of hill agriculture cannot be disregarded, as mountains cover more than 22 percent of the earth's land area and are home to 915 million people, or about 12 percent of the world's population (FAO, 2018). It is also estimated that around 45 percent of world's mountain area is not or only marginally suitable for growing crops, raising livestock or carrying forestry activities (FAO, 2015). There is multitude of problems associated with hill agriculture, although it is diversified due to prevalence of different

How to cite this article: Singh, S. and Hansra, B.S. (2021). Economic Sustainability of Vegetable Farming by Self-Help Group Members and Non Members: An Assertive Study in Himachal Pradesh. Economic Affairs, 66(04): 543-547.

Source of Support: None; Conflict of Interest: None 
microclimatic conditions due to varying altitudes and complex micro-ecosystem. In the hill states like Himachal Pradesh, farmers try to earn livelihood from small and marginal fragmented land holdings, which usually lack irrigation, transportation and market facilities. About 71 percent numbers of landholdings are below 1.0 hectare with average size of 0.40 hectare and about 80 percent of the total cultivated land is rainfed (GoHP, 2021). Due to such limitations, agriculture in hills is uncertain and due to this uncertainty the rural inequalities are increasing and employment opportunities are shrinking (Devi and Karol, 2020). Poverty and unemployment are major problems faced by rural community (Singh et al. 2017). Vegetable farming has paved new path of economic development in hilly states like Himachal Pradesh (Singh and Hansra, 2018) and Landrace vegetables have high economic value and marketing viability and these are good source of income and trade specific activities for the farmers/dwellers (Meena et al. 2016). Area under vegetable production is increasing over years despite gradual fall in total cultivable area in India (Zainab et al. 2020). Vegetables are important constituents of Indian agriculture and nutritional security. Along with health benefits, vegetables help in flourishing countries economy, as it provides a great opportunity for income and employment generation for the farming sector. Increasing production in future should be aimed through improving productivity, as another option of area expansion has restrictions by the increased human dwelling and other economic development activities (Zainab and Umesh, 2021). Vengatesan and Santha (2018) in a study reported that the vast majority of rural people were not involved in development activities because they lacked the economic based frame to intervene in the local development. The self-help groups is conceived as a sustainable people's institution, which provide the poor with the space and support necessary for them to take effective steps towards achieving greater control of their lives in the society (Balamurugan and Jevaseelan, 2018). Self-help group approach has worked well to solve vegetable production constraints (Singh and Hansra, 2021). Empowerment status of the SHG members was reported higher than the non-members and empowerment is positively correlated with the efficiency of the group (Das and Pal, 2020). There are huge numbers of self-help groups involved in vegetable cultivation as a group activity, as it is easy to address problems in groups rather than addressing and representing individual farmer with minuscule production. Self-help group formation enhances farmers' knowledge base, thereby improving vegetable production (Singh and Hansra, 2018). Socioeconomic variable like education, land holding and annual income were reported significantly and positively correlated with knowledge level of farmers (Singh et al. 2015). It has been very well established that providing finance to the poor after organizing them into homogenous group commonly known as SHGs have given statutory results in India and other developing countries, especially among the rural poor women (Bariya et al. 2017). Group involvement have been reported helping in establishing appropriate marketing relationships (Kalra et al. 2013; Bariya et al. 2017, Rahaman and Abdulla, 2018; Shinogi et al. 2017). Adhikari and Das (2019) reported that self-help groups members have higher level of income compared to other farmers. When farmers are adopting vegetable production as a source of livelihood from their small and marginal land holding, it is obvious question that how long such livelihood is going to sustain under changing demographics? Is vegetable production in hills can be sustainable environmentally, economically and socially sustainable in hills? To answer such question present study was planned to find out economic sustainability of vegetable farming in Himachal Pradesh with the specific objectives to develop economic sustainability index (ESI) for vegetable farming, identify the influencing factors and its comparison among SHG members and other farmers in Himachal Pradesh.

\section{METE RIALS AND METHODS}

The study was conducted in the state of Himachal Pradesh covering all three divisions. From each division two districts were randomly selected and from list of self-help groups who grows vegetable, five such groups were selected in each district, thus covering a total of 30 self-help groups from the state. From each selected group, 5 members were selected randomly to collect data on vegetable production and one office bearer of the group, either president/ secretary/treasurer and interviewed to collect data on farming activities by these groups. 150 control 
farmers from the adjacent villages were selected randomly. So the sample size for the proposed study will be 330 (150 group members, 30 office bearers and 150 non-members). Selected SHG members and non-members were directly interviewed using pre-tested structured interview schedule. The information were tabulated, analyzed using appropriate statistical techniques and presented in different groups. Economic Sustainability Index (ESI) was finalized based upon sustainability indicators decided after taking opinion of experts judges in the field by sending them list of indicators to know the importance level of each indicator. Based upon the values of sustainability indices, the vegetable farms of the respondents were categorized as least sustainable, moderately sustainable, sustainable and highly sustainable as per scale developed by Leishangthem et al. (2017).

\section{RESULTS AND DISCUSSION}

Economic sustainability of vegetable farming was examined by considering operational land holding, area under vegetable cultivation, total vegetable production, and vegetable consumption. Indicators viz. production efficiency, net profit and market accessibility to develop economic sustainability index.

\section{Indicators of Economic Sustainability}

(a) Production efficiency: Productivity of the vegetable farms is crucial for economic viability of the farm. Production efficiency of vegetable farms of respondent is presented in Table 1 which reveals that vegetable farms of SHG members have significantly higher production efficiency to that of non-members. Average production efficiency of member's farm was found to be 18.31 tonnes/hectare in comparison to 16.70 tonnes/ hectare to that of non members. Majority of members (63 percent) have high production efficiency followed by medium production efficiency category (27 per cent). In case of non members, majority of the farms (50 percent) found to be in medium category of profitability followed by low (27 percent) production efficiency.

(b) Net profit from vegetable farming: The success of vegetable farms depends on the extent of its profitability and farmer tries to optimize the profit using limited resources. Thus in the present study, efforts have been made to work out net profit generated from vegetable farms of the members and non members, which was measured by deducting the total cost incurred from total returns received. The details of net profit accrued by the members and other vegetable farmers has been depicted in Table 1. Significant difference at one percent level of significance was observed between vegetable farms of members and non-members. Majority of the members' farms (51 per cent) found in medium level of net profit followed by low profit category ( 25 per cent), whereas majority of non-members were found in in low net profit ( 53 per cent) category followed by medium net profit ( 24.33 per cent) category.

(c) Market: Significance of an organized market and proper marketing of farm produce are important

Table 1: Comparison of economic sustainability indicators for SHG members and non-members in Himachal Pradesh

\begin{tabular}{|c|c|c|c|c|c|}
\hline Indicator & $\begin{array}{l}\text { SHG member } \\
(n=150)\end{array}$ & Mean value & $\begin{array}{l}\text { Non-member } \\
(n=150)\end{array}$ & Mean value & $Z$ value \\
\hline \multicolumn{6}{|c|}{ Production efficiency (tonnes/hectare) } \\
\hline Medium (16.0-18.0) & $41(27.33)$ & \multirow[t]{2}{*}{18.31} & $75(50.00)$ & \multirow[t]{2}{*}{16.70} & \multirow[t]{2}{*}{$6.86^{* *}$} \\
\hline High $(>18.00)$ & $95(63.34)$ & & $35(23.33)$ & & \\
\hline \multicolumn{6}{|l|}{ Net profit (₹/year) } \\
\hline Medium (16753-32145) & $76(50.67)$ & \multirow[t]{2}{*}{33082} & $44(24.33)$ & \multirow[t]{2}{*}{25129} & \multirow[t]{2}{*}{$2.73^{*}$} \\
\hline High $(>32145)$ & $36(24.00)$ & & $21(14.00)$ & & \\
\hline \multicolumn{6}{|l|}{ Market access } \\
\hline Formal (3) & $82(54.67)$ & \multirow[b]{2}{*}{2.43} & $32(21.33)$ & \multirow[b]{2}{*}{1.80} & \multirow[b]{2}{*}{$7.39^{* *}$} \\
\hline Both (2) & $51(34.00)$ & & $58(38.67)$ & & \\
\hline
\end{tabular}

Figure in parenthesis indicate percentage; "Significant at 5 percent level; "*significant at 1 percent level. 
Table 2: Economic sustainability Index (ESI) of the respondents' farms

\begin{tabular}{llllllll}
\hline & \multicolumn{4}{c}{ Level of sustainability } & & \multicolumn{2}{c}{ Members } \\
\cline { 2 - 5 } Respondents & $\begin{array}{l}\text { Least } \\
\text { Sustainable } \\
(\mathbf{0 - 0 . 2 5 )}\end{array}$ & $\begin{array}{l}\text { Moderately } \\
\text { Sustainable } \\
\mathbf{( 0 . 2 6 - 0 . 5 0 )}\end{array}$ & $\begin{array}{l}\text { Sustainable } \\
\mathbf{( 0 . 5 1 - 0 . 7 5 )}\end{array}$ & $\begin{array}{l}\text { Highly } \\
\text { sustainable } \\
\mathbf{( 0 . 7 6 - 1 . 0 0 )}\end{array}$ & $\begin{array}{l}\text { Mealue } \\
\text { value }\end{array}$ & SD & $\begin{array}{l}\text { Vs } \\
\text { Non-members } \\
\text { (Z- stat) }\end{array}$ \\
\hline $\begin{array}{l}\text { Members } \\
(\mathrm{n}=150)\end{array}$ & $11(7.33)$ & $74(49.33)$ & $62(41.34)$ & $3(2.00)$ & 0.46 & 0.14 & \\
$\begin{array}{l}\text { Non-Members } \\
(\mathrm{n}=150)\end{array}$ & $46(30.67)$ & $67(46.66)$ & $36(24.00)$ & $1(0.067)$ & 0.35 & 0.16 & $6.06^{* *}$ \\
\hline
\end{tabular}

Figure in parenthesis indicate percent; "* Significant at 1\% level.

for the sustainability of any agriculture enterprise. Marketing of vegetables by the respondent in the state of Himachal Pradesh is depicted in Table 1. Majority of the member respondents (55 per cent) found marketing their produce in formal market, whereas, only 21 percent non members have reach to formal marketing system. SHG member and nonmembers who marketed their produce in formal as well as informal market found to be 34 per cent and 39 percent, respectively. Most of the non members are selling their produce in informal marketing system, whereas only 11 percent members are selling produce in informal markets.

\section{Economic sustainability of vegetable farms of respondents}

The above discussed economic indicators were used to work out the economic sustainability index (ESI) of vegetable farms of the members and non members. Economic sustainability results in financial stability, viability and profitability of vegetable farming. The ESI of the respondents is furnished in Table 2. Which was ranged from 0.07 to 0.88 for SHG members and for non- member it varied between 0.02 to 0.79 . As indicated in the table, mean ESI for vegetable farms of member ( 0.46 percent) was higher as compare to that of vegetable farms of non member ( 0.35 percent).

It is further observed that majority of members' farms were moderately sustainable category (49 per cent) to sustainable (41) and only 2 per cent of members' farms were highly sustainable. Majority of non member farms (47\%) found in moderately sustainable category followed by least sustainable $(30.67 \%)$. Less than one percent of non member farm found highly sustainable. Significantly high production efficiency, net profit and good market approach of SHG member might be factors for higher sustainability of vegetable farms of members to that of non- member.

\section{Relationship of independent variables with economic sustainability index}

The relationship of various independent variables with economic sustainability index (ESI) is presented in Table 3. It is observed that out of eight characteristics studied, four were found having positive and significant association with ESI. The characteristics namely education status, operational land holding, vegetable production, and extension contacts of the farmer were found to have positive and significant association with ESI. Other variable like age, experience, number of training and media exposure were found to have no association with ESI. Higher level of education, extension contacts and training might have increased knowledge gain and adoption level of improved vegetable farming practices, which in turn improved production efficiency of the vegetable farms.

Table 3: Relation of independent variables with ESI

\begin{tabular}{lll}
\hline $\begin{array}{l}\text { S1. } \\
\text { No. }\end{array}$ & Variable & $\begin{array}{l}\text { Correlation } \\
\text { coefficient " } \mathrm{r}^{\text {" }}\end{array}$ \\
\hline 1 & Age & $-0.198^{\mathrm{NS}}$ \\
2 & Education & $0.284^{* *}$ \\
3 & Experience & $0.008^{\mathrm{NS}}$ \\
4 & Operational land holding & $0.341^{* *}$ \\
5 & Number of trainings & $0.083^{\mathrm{NS}}$ \\
6 & Vegetable production (tones/year) & $0.311^{* *}$ \\
7 & Media exposure & $0.193^{\mathrm{NS}}$ \\
8 & Extension contacts & $0.477^{* *}$ \\
\hline
\end{tabular}

Significant at 1 percent level of probability.

Vegetable production per year increased economic sustainability of the farms, which might be due to 
the fact that more income was generated from more land holding by selling of vegetables.

\section{CONCLUSION}

Self-help group approach found to be helpful in increasing economic sustainability of vegetable farming. Various economic sustainability indicators like production efficiency, net profit and market orientation found to be significantly higher for SHG members when compared to non-members. The possible reason for this might be group dynamics and group problem solving methods. Economic sustainability of SHG member farms found to significantly higher but on scale economic sustainability index mostly found to be performing from moderately sustainable to sustainable only, which indicate a huge scope of improvement in terms of economic performance. Only few vegetable farms performed in highly sustainable side of scale that clearly indicate huge scope for improvement in terms of economic sustainability for both categories of farmers although self help group approach tends to cope up with the gap of sustainability in vegetable farms. Independent variable like education, land holding, vegetable production and extension contacts found to play positive role in economic sustainability index and policy intervention is required to strengthen involvement of farmers in self-help groups can play a vital role in strengthening economic sustainability index of hill farms.

\section{REFERENCES}

Balamurugan, P. and Jeyaseelan, P. 2018. Self- Help Groups and Renovation of Rural Tanks for Sustainable Rural Livelihoods: A Study in Cuddalore District, Tamil Nadu. Int. J. Inclusive Develop., 4(1): 21-26.

Bariya, M.K., Chhodvadia, H.C., Patel, H., Parmar, S. and Vyas, J. 2017. Study on Proile Characteristics of Women Self-Help Group Members. J. Krishi Vigyan, 5(2): 154-159.

Das, R. and Pal, K.P. 2020. Self-Help Groups (SHGs) and Women Empowerment: A study in Cooch Behar District of West Bengal, India. Int. J. Inclusive Develop., 6(1): 0105 (June 2020).

FAO. 2018. Mountain Partnership [online]. Rome. [cited 25 July 2018]. www.fao.org/mountain-partnership/en/ on 25 July 2018.

FAO. 2015. Mapping the vulnerability of mountain people to food security. Rome (www.fao.org/31a-i517se.pdf)
Government of Himachal Pradesh, 2021. Economic Survey. Saving Lives and Livelihood..2020-21.https:// himachalservices.nic.in/economics/en-IN/economicsurvey.html

Leishangthem, G., Feroze, D., Feroze, S.M., Singh, R. and Sarker, A. 2017. Sustainability of Hill Agriculture in North eastern Himalayas; Estimate from Manipur, India. J. of Com. Mob. Sust. Develop., 12(2): 286-294.

Singh, D.K., Pandey, N.K., Rana. R.K. and Singh, B.P. 2015. Extent and correlates of knowledge of farmers regarding scientific potato production technologies in Himachal Pradesh. Int. J. Agri. Env. Biotech., 8(2): 381-385.

Devi, M. and Karol, S. 2020. Sustainability Issues of Food crops in Himachal Pradesh. Ind. J. Resear., 9(4): 7-10.

Singh, S. and Hansra, B.S. 2021. Minimizing Vegetable Production Constraints in Hills: Boon to Attain Sustainable Vegetable Farming System. Ind. J. Extn. Edu., 57(1): 52-55.

Singh, S. and Hansra, B.S. 2018. A Study on Environmental Sustainability Index of Vegetable Farming in Himachal Pradesh. Int. J. Agri. Env. Biotech., 11(5): 713-717.

Singh, S., Raman, N.L.M. and Hansra. B.S. 2017. Perspectives of Agritourism in Himachal Pradesh: A New Dimension in Hill Agricultural Diversification. J Community Mobil Sustainable Develop., 12(2): 207-215.

Vengatesan, D. and Santha, G. 2018. Development of Socioeconomic Status Scale for Women Self-Help Group Members. Int. J. Inclus. Develop., 4(1): 09-13.

Abdul-Rahaman, A. and Abdulai, A. 2018. Do farmer groups impact on farm yield and efficiency of smallholder farmers? Evidence from rice farmers in northern Ghana. Food Policy, 81: 95-105.

Adhikary, M. and Das, S.K. 2019. Impact of Self-Help Group (SHG) Membership on Income and Income Inequality: A Case Study of Birbhum District in West Bengal. Handbook of Research on Microfinancial Impacts on Women Empowerment, Poverty, and Inequality, pp. 341-364.

Meena, S.R., Sharma, B.D., Singh, R.S. and Singh, D. 2016. Economic return from the landrace vegetables and their importance in sustainable production systems in the hot arid region. Econ. Affairs, 61(1): 1-9.

Shinogi, K.C., krishanankutty, J., Krishnan, S., Srivastava, S. and Gills, R. 2017. Market-led Extension and Empowerment of Small Holder Vegetable Farmers in India. Int. J. Bio-resourc. Stress Manag., 8(1): 104-109.

Kalra, R.K., Anil, B., Mathew, A, Tonts., Siddique, K. 2013. Self-Help Groups in Indian Agriculture. Agroecology and Sustainable Farming Sys., 37(5): 509-530.

Zainab BI. A., Umesh, K.B., Sreeniwas Murthy, D., Srikantha Murthy, P.S., Narse Gowda, N.C. and Manjunath, V. 2020. Dynamics of Area Change in Vegetable Production in Karnataka. Econ. Aff., 65(4): 499-504.

Zainab BI. A. and Umesh, K.B. 2021. Growth in Vegetable Production and its Decomposition in Karnataka. Econ. Aff., 66(1): 79-84. 
